\title{
Effect of Lactoperoxidase System on Microbiological and Quality Markers of Minimally Processed Lettuce
}

\author{
Ameni Telmoudi*, Mnasser Hassouna \\ École Supérieure des Industries Alimentaires de Tunis (ESIAT), Unité de Recherche "Bio-conservation et Valorisation des \\ Produits Agro-alimentaires" (UR13AGR02, ESIAT), Tunis, Tunisie \\ Email: *ameni.telmoudi@yahoo.fr
}

How to cite this paper: Telmoudi, A. and Hassouna, M. (2017) Effect of Lactoperoxidase System on Microbiological and Quality Markers of Minimally Processed Lettuce. Technology and Investment, 8, 121-130. https://doi.org/10.4236/ti.2017.82010

Received: March 16, 2017

Accepted: May 24, 2017

Published: May 27, 2017

Copyright @ 2017 by authors and Scientific Research Publishing Inc. This work is licensed under the Creative Commons Attribution International License (CC BY 4.0).

http://creativecommons.org/licenses/by/4.0/

\section{(c) (i) Open Access}

\begin{abstract}
Minimally processed lettuce is sensitive to microbial attack caused by the loss of natural resistance and their high water content and nutrients. The use of natural anti-microbial agents such as the lactoperoxidase system (LPS) represents an interesting alternative to the use of chemical treatments. This study focused on the importance of LPS and its efficiency as a bioprotective agent. The effect of washing with LPS, at two different concentrations (4 and 5 IU) and four different treatment times (1,2,3 and $4 \mathrm{~h})$ on microbial growth in fresh-cut lettuce, was determined at $30^{\circ} \mathrm{C}$ and compared with a $80 \mathrm{ppm}$ chlorine at $4^{\circ} \mathrm{C}$ for $20 \mathrm{~min}$. The results deduced that both doses of LPS showed significant reductions in microbial growth when applied during $4 \mathrm{~h}$, but the highest dose proved to be more effective. No significant differences were found between the LPS treatment and chlorine considering native microflora reduction and quality markers during storage.
\end{abstract}

\section{Keywords}

Antimicrobial Effect, Lactoperoxidase System, Minimally Processed Lettuce, Quality Markers

\section{Introduction}

Minimally processed lettuce form an important component of a healthy diet and is a convenient way to increase the consumption of this fresh vegetable [1]. This fresh product, however, is sensitive to microbial attack after harvest caused by the loss of natural resistance and their high water content and nutrients, a problem that can be worsened by minimal processing. To maintain the microbiological quality and safety of minimally processed fresh vegetables, these products 
are normally packaged in modified atmospheres and effective refrigerated temperature control during manufacture, distribution and retailing are required. Unfortunately, these steps do not remove either or retard microbial spoilage of these products entirely [1] [2]. The dominant bacterial population of lettuce at low temperatures during storage consists mainly of species.

Disinfection using hypochlorite is currently used by a majority (76\%) of fresh produce manufacturers to enhance safety and shelf-life profiles. Water containing $50-200 \mathrm{ppm}$ of chlorine is used extensively in food processing plants to disinfect whole fruits and vegetables as well as fresh-cut produce. However, chlorine does not ensure elimination or even an efficient reduction in the number of bacteria [3]. In addition to such limited efficacy, chlorinated organic compounds, such as trihalomethanes, can be produced when the chlorine contacts the organic matter. Due to these problems, new awareness to reduce the usage of the chemical treatments by developing alternative strategies or technologies in order to improve fresh cut vegetables disease resistance and control of pathogens are being promoted. Biological control well suited for this new trend and Lactoperoxidase system (LPS) has been identified as bioprotective agents [4].

LPS name points out the dairy origin [5]. This system consists of the lactoperoxidase enzyme and two substrates: the hypothiocyanate ion $\left(\mathrm{OSCN}^{-}\right)$and hydrogen peroxide $\left(\mathrm{H}_{2} \mathrm{O}_{2}\right)$. The antimicrobial element of LPS, namely the hypothiocyanate ion $\left(\mathrm{OSCN}^{-}\right)$, is the reaction between thiocyanate and hydrogen peroxide, catalysed by lactoperoxidase [6]. Antimicrobial activity of this system has been shown for a number of bacteria, fungi and viruses [5] [7].

The main objective of this work was to optimize the application of lactoperoxidase system (LPS) for minimally processed lettuce decontamination. Moreover, the effect of the LPS system on the control of spoilage microflora and improving shelf-life characteristics during lettuce storage was determined.

\section{Materials and Methods}

\subsection{Lactoperoxidase System}

Lactoperoxidase enzyme (200 IU/mg) was donated by Sigma-Aldrich (France), glucose oxidase (Sigma-Aldrich, France) and glucose were used as a peroxide generator system and sodium thiocyanate $(\mathrm{NaSCN})$ were purchased from Sigma-Aldrich (France).

\subsection{Preparation of Vegetable Model Lettuce}

Biological iceberg lettuce were harvested at optimal maturity. Samples were then transferred to the laboratory within $1 \mathrm{~h}$ under refrigeration conditions and stored up to $24 \mathrm{~h}$ at $4^{\circ} \mathrm{C}$ before treatment. Three external leaves were removed by hand (using sterile gloves) and the other parts of the lettuce were shredded in pieces of approximately $2 \mathrm{~cm}^{2}$, using a sterile blade. Three separate treatment solutions were prepared using distilled water. The concentrations were 4 and 5 IU for LPS, $80 \mathrm{ppm}$ for chlorine and temperatures were 30 and $4^{\circ} \mathrm{C}$ respectively 
[8]. Prepared lettuce was placed in the appropriate treatment solution with gentle agitation during $20 \mathrm{~min}$ for chlorine and 1, 2, 3 and $4 \mathrm{~h}$ for LPS, prior to rinsing in distilled water for $1 \mathrm{~min}$. The ratio of samples to treatment solution was 1:10 w/v. Treated lettuces were rinsed with distilled water for 1 min [8]. They were then spin-dried, divided into $10 \mathrm{~g}$ of portions and placed into plastic bags. All bags were treated as individual samples and stored at $4^{\circ} \mathrm{C}$. Unwashed samples and samples treated with chlorine water were used as controls for Shredded lettuce washed with LPS.

\subsection{Microbiological Analysis}

Microbiological analysis was performed on hour, 1, 2, 3 and 4 to determine the effect of LPS concentration and contact time applied.

The enumeration of the microbial population was made according to Guireaud et al. (1998) [9]. Each $10 \mathrm{~g}$ of lettuce was washed in a bag containing 90 $\mathrm{mL}$ of sterile peptone water with shaking. The homogenate was diluted decimally in peptone water. $1 \mathrm{~mL}$ of the diluted samples were transferred on plate count agar (PCA) (Merck, Darmstadt, Germany) to enumerate mesophilic aerobic bacteria (MES) and incubated at $30^{\circ} \mathrm{C}$ for $48 \mathrm{~h}$. Psychrotrophic bacteria (PSC) was performed in the same medium but incubated at $6^{\circ} \mathrm{C}$ for $5-7$ days. Total coliforms (TC) in Desoxycholate 1\%o agar (Merck, Darmstadt, Germany) incubated at $37^{\circ} \mathrm{C}$ for $24 \mathrm{~h}$. Lactic acid bacteria (LAB) in Man, Rogosa and Sharpe agar (MRS) (Merck) incubated at $37^{\circ} \mathrm{C}$ for $48 \mathrm{~h}$. Molds and yeast (MY) in Sabouraud Chloramphenicol agar (Merck, Darmstadt, Germany) incubated at $25^{\circ} \mathrm{C}$ for 5 days. Each analysis was carried out in triplicate. Results were expressed as $\log _{10} \mathrm{CFU} \mathrm{g}{ }^{-1}$.

To investigate the LPS effect on the preservation of fresh lettuce, samples were stored in refrigerator $\left(4^{\circ} \mathrm{C}\right) 7$ days and microbiological analyses were conducted on treatment day and on 1 st, $2 \mathrm{nd}, 3 \mathrm{rd}$, 5 th and 7 th days of the refrigerated storage.

\subsection{Shelf-Life Analysis}

The objective was to study the effect of LPS on the quality of minimally processed lettuce. Weight loss, colour and $\mathrm{pH}$ were evaluated as indicators of shelf-life. Shelf-life is defined as the length of time at which the vegetable can maintain the appearance and safety [10], therefore markers were measured from samples treated with LPS and compared to those obtained using chlorine on days $0,1,2,3,5$ and 7 .

\subsubsection{Weight Loss}

Samples were weighed immediately after treatment ( $I W$, initial weight) and then, after removal from refrigerated storage ( $S W$, storage weight). Weight loss of each individual sample was calculated as:

$$
W L(\%)=(1-S W / I W) \times 100
$$

$W L$ was expressed as percentage of weight loss with respect to initial mass. 


\subsubsection{Colour Measurement}

Color measurements of lettuce were performed using a colorimeter (Minolta CR-300, Japan) to measure the CIE color space co-ordinates, $L^{\star}, a^{\star}$ and $b^{*}$ (lightness, red value and yellow value, respectively, on the Hunter scale). The colorimeter was calibrated with a white tile standard.

\subsection{3. $\mathrm{pH}$}

Ten grams of lettuce was blended for $2 \mathrm{~min}$ in $20 \mathrm{~mL}$ of deionised water. The $\mathrm{pH}$ of the slurry was determined at room temperature using a $\mathrm{pH}$-meter (Hach Company Electrochemical Meters).

\subsection{Statistical Analysis}

The mean values obtained from the microbiological evaluation of lettuce were analyzed by one one-way ANOVA procedure of SPSS ${ }^{\circ}$ 17.0. Duncan's multiple range tests were used to determine any significant difference between mean values and evaluations as based on a significance level of $p<0.05$.

\section{Results and Discussion}

\subsection{Effect of LPS Concentration and Time Contact on the Natural Microflora of Lettuce}

Table 1 shows microbial counts in shredded lettuce after treatment with LPS and Chlorine. The effect of LPS after $1 \mathrm{~h}$ of treatment, on MES, PSC, TC, and YM was significantly different $(p<0.05)$ to unwashed samples. For LAB, significant reductions were obtained with dose application of $5 \mathrm{IU}$ after two hours. The effect of the LPS can be bactericidal against the Gram negative bacteria or bacteriostatic against Gram-positive bacteria [7] (Marshall and Reiter, 1980). In

Table 1. Survival of MES, PSC, TC, LAB and YM on minimally processed lettuce treated with LPS (doses 4 and $5 \mathrm{IU}$ ) and chlorine.

\begin{tabular}{cccccc}
\hline Treatment & MES & PSC & TC & LAB & YM \\
\hline NTC & $6.5 \pm 6.2^{\mathrm{A}}$ & $4.4 \pm 4.2^{\mathrm{A}}$ & $4.9 \pm 3.9^{\mathrm{A}}$ & $5.3 \pm 4.7^{\mathrm{A}}$ & $5.9 \pm 4.2^{\mathrm{A}}$ \\
1 LPS 1 & $6.0 \pm 4.8^{\mathrm{B}}$ & $4.3 \pm 4.2^{\mathrm{B}}$ & $4.7 \pm 4.1^{\mathrm{B}}$ & $5.3 \pm 4.7^{\mathrm{A}}$ & $5.6 \pm 4.2^{\mathrm{B}}$ \\
1 LPS 2 & $6.0 \pm 4.8^{\mathrm{BC}}$ & $4.0 \pm 1.8^{\mathrm{B}}$ & $4.0 \pm 3.0^{\mathrm{C}}$ & $5.2 \pm 4.8^{\mathrm{A}}$ & $5.1 \pm 1.8^{\mathrm{C}}$ \\
2 LPS 1 & $5.9 \pm 4.6^{\mathrm{CD}}$ & $4.1 \pm 3.8^{\mathrm{C}}$ & $4.4 \pm 4.2^{\mathrm{D}}$ & $5.2 \pm 4.6^{\mathrm{A}}$ & $4.9 \pm 3.8^{\mathrm{CD}}$ \\
2 LPS 2 & $5.7 \pm 4.8^{\mathrm{E}}$ & $3.1 \pm 2.2^{\mathrm{D}}$ & $3.9 \pm 3.2^{\mathrm{E}}$ & $4.2 \pm 3.7^{\mathrm{BC}}$ & $4.2 \pm 2.2^{\mathrm{D}}$ \\
3 LPS 1 & $5.9 \pm 4.6^{\mathrm{D}}$ & $4.0 \pm 3.4^{\mathrm{C}}$ & $3.7 \pm 3.0^{\mathrm{F}}$ & $4.9 \pm 4.2^{\mathrm{D}}$ & $4.0 \pm 3.4^{\mathrm{D}}$ \\
3 LPS 2 & $4.1 \pm 3.3^{\mathrm{F}}$ & $2.9 \pm 2.0^{\mathrm{EF}}$ & $2.9 \pm 2.0^{\mathrm{G}}$ & $4.0 \pm 2.8^{\mathrm{BC}}$ & $3.0 \pm 2.0^{\mathrm{E}}$ \\
4 LPS 1 & $5.6 \pm 5.4^{\mathrm{E}}$ & $3.0 \pm 1.8^{\mathrm{DE}}$ & $2.3 \pm 2.0^{\mathrm{H}}$ & $4.4 \pm 4.2^{\mathrm{B}}$ & $3.7 \pm 1.8^{\mathrm{F}}$ \\
4 LPS 2 & $3.6 \pm 2.9^{\mathrm{G}}$ & $\mathrm{ND}^{\mathrm{G}}$ & $\mathrm{ND}^{\mathrm{I}}$ & $3.8 \pm 3.0^{\mathrm{C}}$ & $2.2 \pm 0.0^{\mathrm{E}}$ \\
Chlorine & $3.9 \pm 3.1^{\mathrm{H}}$ & $2.8 \pm 2.0^{\mathrm{F}}$ & $\mathrm{ND}^{\mathrm{I}}$ & $2.4 \pm 1.9^{\mathrm{C}}$ & $1.8 \pm 2.0^{\mathrm{E}}$
\end{tabular}

MES: total mesophyllic bacteria count, PSC: total psychrophilic bacteria count, TC: total coliforms, LAB: lactic acid bacteria and YM: total yeast and molds count. Counts are expressed in $\log _{10} \mathrm{CFU} \mathrm{g}^{-1}$ ( \pm standard deviation). Different letters in the same column indicate significant differences $(p<0.05)$. The concentrations used for each treatment were the following: LPS 1 (4 IU), LPS 2 (5 IU) and chlorine (80 ppm). The number used before LPS is the number of hours of treatment. NTC: non-treated control. 
fact, this difference in sensitivity can probably explained by the differences in cell wall structure and their different barrier propreties [11]. The inner membrane of Gram positive bacteria appears to be less extensively damaged by LPS treatment that than of Gram negative species [7].

Changes in the mean values of $\mathrm{CFU} \mathrm{g} \mathrm{g}^{-1}$ in $\log _{10}$, the main groups of lettuce contaminant bacteria, measured at $4 \mathrm{~h}$ post activation of LPS, indicate the best decrease of the total amount, independently of the applied dose. For example, reduction of YM with $0.3,1,1.9$ and $2.2 \log$ units were obtained after 1, 2, 3 and $4 \mathrm{~h}$ of treatment with the lowest dose of LPS (4 IU), respectively. These results confirm a previous report in which LPS was effective on reducing microorganisms growth in vegetable juices, the reduction becomes important after $4 \mathrm{~h}$ of contact [12].

The use of two doses of LPS has been determinant for the effective selection of appropriate concentration, since for all microbial group differed between 4 and 5 IU of lactoperoxidase used for $4 \mathrm{~h}$. Indeed, the best reductions were observed for the higher dose (5 IU).

When LPS was used for $4 \mathrm{~h}$, the effect on TC, LAB and YM was the same as that observed with the Chlorine ( $p>0.05)$. For MES and PSC, a significant inhibitory effect was found with LPS in comparison to the chlorinated water. Thus, from a microbiological point of view, LPS is a viable alternative to chlorine as decontamination treatments.

Sagoua et al. (2011) [13] showed that the LPS had a significant inhibitory effect on the microbial growth. Nguyen et al. (2005) [14] also showed the effect of LPS on the growth of two mango pathogens, Colletotrichum gloeosporioides and Botryodiplodia theobromae. They demonstrated that the inhibitory effect was due to $\mathrm{OSCN}^{-}$ions produced by the lactoperoxidase system and not to the hydrogen peroxide present in the system. In these experiments, the source of hydrogen peroxide was glucose oxidase in salt solutions.

Finally, we selected $5 \mathrm{IU}$ for lactoperoxidase dose and $4 \mathrm{~h}$ of contact for the rest of our study.

\subsection{Effect of LPS and Chlorine on the Natural Microflora of Lettuce during Storage}

Reduction of the indigenous flora of lettuce because of decontamination with watery suspensions of LPS and chlorine are shown in Table 2. Washing of two lettuce samples in the different water (LPS and chlorine) resulted in similar reduction of indigenous flora in both samples.

If decontamination of lettuce sample was performed with LPS solution a reductions of 3.3, 4.9 4.6, 3.1 and 3.6 $\log _{10} \mathrm{CFU} \mathrm{g}^{-1}$, respectively, were observed for MES, PSC, TC, LAB and YM. These reductions were important throughout the cold storage. The sensibility of MES and PSC to LPS has been previously cited for Björck (1978) [15] who showed that the numbers of these bacteria decreased markedly in the raw milk, inter alia, growth of this microbial population was strongly inhibited by the presence of LPS. Similarly, the publications of the 
Table 2. Survival of MES, PSC, TC, LAB and YM on minimally processed lettuce treated with LPS (5 IU) and chlorine during storage $\left(0-7\right.$ days at $\left.4^{\circ} \mathrm{C}\right)$.

\begin{tabular}{|c|c|c|c|c|}
\hline \multirow{2}{*}{ Time (days) } & \multirow{2}{*}{$\begin{array}{l}\text { Bacterial } \\
\text { population }\end{array}$} & \multicolumn{3}{|c|}{ Treatment } \\
\hline & & LPS & Chlorine & $N T C$ \\
\hline \multirow{5}{*}{0} & MES & $3.5 \pm 3.5^{\mathrm{A}}$ & $3.8 \pm 3.8^{\mathrm{A}}$ & $6.8 \pm 6.0^{\mathrm{B}}$ \\
\hline & PSC & $\mathrm{ND}^{\mathrm{A}}$ & $1.1 \pm 0.8^{\mathrm{A}}$ & $4.9 \pm 4.2^{\mathrm{B}}$ \\
\hline & TC & $\mathrm{ND}^{\mathrm{A}}$ & $\mathrm{ND}^{\mathrm{A}}$ & $4.6 \pm 4.2^{\mathrm{B}}$ \\
\hline & $\mathrm{LAB}$ & $1.6 \pm 1.2^{\mathrm{A}}$ & $1.5 \pm 1.0^{\mathrm{A}}$ & $4.7 \pm 3.8^{\mathrm{B}}$ \\
\hline & YM & $2.1 \pm 1.8^{\mathrm{A}}$ & $1.1 \pm 0.8^{\mathrm{A}}$ & $5.7 \pm 5.7^{\mathrm{B}}$ \\
\hline \multirow{5}{*}{1} & MES & $3.5 \pm 3.5^{\mathrm{A}}$ & $3.8 \pm 3.8^{\mathrm{A}}$ & $8.6 \pm 8.6^{\mathrm{B}}$ \\
\hline & PSC & $1.4 \pm 0.8^{\mathrm{A}}$ & $1.5 \pm 1.0^{\mathrm{A}}$ & $4.8 \pm 4.5^{\mathrm{B}}$ \\
\hline & TC & $\mathrm{ND}^{\mathrm{A}}$ & $\mathrm{ND}^{\mathrm{A}}$ & $4.6 \pm 4.1^{\mathrm{B}}$ \\
\hline & $\mathrm{LAB}$ & $1.7 \pm 1.3^{\mathrm{A}}$ & $1.7 \pm 1.5^{\mathrm{A}}$ & $5.7 \pm 5.5^{\mathrm{B}}$ \\
\hline & YM & $2.2 \pm 2.1^{\mathrm{A}}$ & $1.7 \pm 1.4^{\mathrm{A}}$ & $5.8 \pm 5.7^{\mathrm{B}}$ \\
\hline \multirow{5}{*}{2} & MES & $3.8 \pm 3.6^{\mathrm{A}}$ & $4.1 \pm 3.9^{\mathrm{A}}$ & $8.7 \pm 8.6^{\mathrm{B}}$ \\
\hline & PSC & $2.5 \pm 2.2^{\mathrm{A}}$ & $2.0 \pm 1.0^{\mathrm{A}}$ & $4.5 \pm 4.0^{\mathrm{B}}$ \\
\hline & $\mathrm{TC}$ & $\mathrm{ND}^{\mathrm{A}}$ & $\mathrm{ND}^{\mathrm{A}}$ & $4.7 \pm 4.1^{\mathrm{B}}$ \\
\hline & $\mathrm{LAB}$ & $2.9 \pm 2.3^{\mathrm{A}}$ & $3.6 \pm 3.5^{\mathrm{A}}$ & $6.8 \pm 6.4^{\mathrm{B}}$ \\
\hline & YM & $2.5 \pm 1.8^{\mathrm{A}}$ & $1.7 \pm 1.4^{\mathrm{A}}$ & $6.6 \pm 6.7^{\mathrm{B}}$ \\
\hline \multirow{5}{*}{3} & MES & $4.2 \pm 3.9^{\mathrm{A}}$ & $4.2 \pm 4.1^{\mathrm{A}}$ & $10.0 \pm 9.5^{\mathrm{B}}$ \\
\hline & PSC & $3.7 \pm 3.3^{\mathrm{A}}$ & $3.1 \pm 2.2^{\mathrm{A}}$ & $6.4 \pm 5.8^{\mathrm{B}}$ \\
\hline & $\mathrm{TC}$ & $\mathrm{ND}^{\mathrm{A}}$ & $\mathrm{ND}^{\mathrm{A}}$ & $5.0 \pm 4.0^{\mathrm{B}}$ \\
\hline & $\mathrm{LAB}$ & $2.8 \pm 2.4^{\mathrm{A}}$ & $2.9 \pm 2.5^{\mathrm{A}}$ & $7.7 \pm 7.6^{\mathrm{B}}$ \\
\hline & YM & $2.8 \pm 2.4^{\mathrm{A}}$ & $3.7 \pm 3.6^{\mathrm{A}}$ & $6.4 \pm 6.4^{\mathrm{B}}$ \\
\hline \multirow{5}{*}{5} & MES & $5.5 \pm 5.6^{\mathrm{A}}$ & $5.6 \pm 5.6^{\mathrm{A}}$ & $10.8 \pm 10.9^{\mathrm{B}}$ \\
\hline & PSC & $5.8 \pm 5.2^{\mathrm{A}}$ & $5.4 \pm 5.2^{\mathrm{A}}$ & $7.7 \pm 7.3^{\mathrm{B}}$ \\
\hline & $\mathrm{TC}$ & $1.0 \pm 1.0^{\mathrm{A}}$ & $1.0 \pm 1.0^{\mathrm{A}}$ & $5.9 \pm 5.4^{\mathrm{B}}$ \\
\hline & LAB & $3.9 \pm 3.4^{\mathrm{A}}$ & $3.9 \pm 3.4^{\mathrm{A}}$ & $8.6 \pm 7.8^{\mathrm{B}}$ \\
\hline & YM & $4.9 \pm 3.8^{\mathrm{A}}$ & $4.6 \pm 4.2^{\mathrm{A}}$ & $8.5 \pm 8.6^{\mathrm{B}}$ \\
\hline \multirow{5}{*}{7} & MES & $7.8 \pm 7.3^{\mathrm{A}}$ & $7.6 \pm 7.4^{\mathrm{A}}$ & $12.2 \pm 11.6^{\mathrm{B}}$ \\
\hline & PSC & $6.6 \pm 6.6^{\mathrm{A}}$ & $6.6 \pm 6.5^{\mathrm{A}}$ & $8.7 \pm 8.2^{\mathrm{B}}$ \\
\hline & $\mathrm{TC}$ & $2.3 \pm 2.3^{\mathrm{A}}$ & $2.5 \pm 2.3^{\mathrm{A}}$ & $7.7 \pm 7.5^{\mathrm{B}}$ \\
\hline & $\mathrm{LAB}$ & $4.9 \pm 4.0^{\mathrm{A}}$ & $4.8 \pm 4.4^{\mathrm{A}}$ & $10.8 \pm 10.1^{\mathrm{B}}$ \\
\hline & YM & $5.8 \pm 5.5^{\mathrm{A}}$ & $5.6 \pm 5.3^{\mathrm{A}}$ & $8.8 \pm 8.3^{\mathrm{B}}$ \\
\hline
\end{tabular}

MES: total mesophyllic bacteria count, PSC: total psychrophilic bacteria count, TC: total coliforms, LAB: lactic acid bacteria and YM: total yeast and molds count; LPS, Chlorine: lettuce samples treated by the LPS and chlorine respectively; NTC: non-treated control; ND: No detected; Values are means of three replicates and counts are expressed in $\log _{10} \mathrm{CFU} \mathrm{g}^{-1}$ ( \pm standard deviation); Means followed by different letters are significantly different $(\mathrm{p}<0.05)$ for each bacterial population.

French Food Safety Agency [8] described the opinion concerning the authorization of using a lactoperoxidase system as a processing aid for the treatment of fresh-cut, ready-to-eat salads. This process actually seems to have the same effect as chlorine as a processing aid, in fresh-cut, ready-to-eat production conditions, and this for the microbiological indicators used in this sector (mesophilic aerobic flora), providing the operating conditions are the same as in the submitted file [16]. Our results also reported that MES were affected by chlorine as there were affected by the LPS.

The mean aerobic mesophilic counts were 5.5 and $5.6 \log _{10} \mathrm{CFU} \mathrm{g}{ }^{-1}$ for LPS and chlorines samples respectively after 5 days of storage, indicating that all 
treated samples were acceptable for consumption because the aerobic bacterial count for lettuce fresh is less than $7.7 \log _{10} \mathrm{CFU} \mathrm{g}^{-1}$ [17].

\subsection{Shelflife Analysis}

\subsubsection{Weight Loss}

Fresh-cut lettuce is very susceptible to weight loss which is due to moisture loss. Yet, the relative humidity is generally very high inside the bags, so dehydration is not a common problem when lettuce are packaged [18]. As the weight loss is an indicator of quality retention, this was monitored during storage for this fresh-cut vegetable. No significant $(p>0.05)$ decrease in weight loss was observed during the first two days in both treated samples, with significant differences between treatments and control (Table 3). Samples treated with the chlorine showed higher weight loss than samples treated with LPS from day 3 to 7 . This weight loss corresponds to the natural catabolism process in vegetable commodities, catalysed by enzymes and accelerated by the minimal processing [19].

\subsubsection{Colour}

Colour was monitored in all the samples during the entire storage (Table 3). Luminosity values $\left(\mathrm{L}^{*}\right)$ decreased during storage, and this can be explained by the appearance of browning. Compared with a control treatment (chlorine), LPS samples showed similar values in luminosity $(\mathrm{p}>0.05)$ during the 5 first days of storage.

Another colour parameter related to browning [20] (Castaner et al. 1999) and to the degradation of chlorophyll [21] is $\mathrm{a}^{*}$ value. This Redness/greenness parameter $\left(a^{*}\right)$ significantly $(p<0.05)$ increased during the storage. These decreases in green colour were coupled with an increase in red colour $\left(b^{*}\right)$ responding to the browning appearance.

\subsection{3. $\mathrm{pH}$}

The initial $\mathrm{pH}$ of the lettuce is 6.52 (Table 3), but as reported by Seifu et al. (2005) [22] the optimum pH for LPS activity is comprised inter 5 and 6 . The enhanced bactericidal effect of this system at low $\mathrm{pH}$ may be due mainly to protonation of the oxidation products. At acidic $\mathrm{pH}$, the major oxidation product is known to be hypothiocyanous acid (HOSCN, pKa 5.3). HOSCN, being uncharged, could more readily diffuse through the hydrophobic bacterial membrane than the hypothiocyanate ion to oxidize intracellular components [23]. Nonetheless, after $4 \mathrm{~h}$ exposure to the LPS, the enhanced bactericidal effect of the system can be improved because of the accumulation of the oxidation products [12].

A general decrease of $\mathrm{pH}$ was observed over storage, which could be due to an increase in the bacterial growth [24] [25]. Samples treated with LPS showed highest $\mathrm{pH}$ values from day 1 to 7 than samples treated with the chlorine.

\section{Conclusions}

The results showed that the variable time of exposure to different LPS doses 
Table 3. Effect of storage and treatment (LPS and chlorine) on $\mathrm{pH}$, weight loss (\%) and colour in fresh-cut lettuce stored at $4^{\circ} \mathrm{C}$ for 7 days.

\begin{tabular}{|c|c|c|c|c|}
\hline \multirow{2}{*}{ Time (days) } & \multirow[t]{2}{*}{ Parameter } & \multicolumn{3}{|c|}{ Treatment } \\
\hline & & LPS & Chlorine & NTC \\
\hline \multirow{5}{*}{0} & $\mathrm{pH}$ & $6.38 \pm 0.01^{\mathrm{A}}$ & $6.25 \pm 0.09^{\mathrm{B}}$ & $6.52 \pm 0.09^{\mathrm{C}}$ \\
\hline & WL & $0.00 \pm 0.00^{\mathrm{A}}$ & $0.00 \pm 0.00^{\mathrm{A}}$ & $0.00 \pm 0.00^{\mathrm{A}}$ \\
\hline & $\mathrm{L}$ & $61.71 \pm 1.15^{\mathrm{A}}$ & $64.59 \pm 2.17^{\mathrm{A}}$ & $64.43 \pm 1.11^{\mathrm{A}}$ \\
\hline & $\mathrm{a}$ & $-16.39 \pm 0.47^{\mathrm{A}}$ & $-15.54 \pm 0.03^{\mathrm{A}}$ & $-16.19 \pm 1.86^{\mathrm{A}}$ \\
\hline & $\mathrm{b}$ & $30.60 \pm 0.01^{\mathrm{A}}$ & $28.91 \pm 0.30^{\mathrm{B}}$ & $30.44 \pm 0.28^{\mathrm{A}}$ \\
\hline \multirow{5}{*}{1} & $\mathrm{pH}$ & $6.36 \pm 0.17^{\mathrm{A}}$ & $6.21 \pm 0.06^{\mathrm{B}}$ & $6.35 \pm 0.76^{\mathrm{A}}$ \\
\hline & WL & $0.66 \pm 0.01^{\mathrm{A}}$ & $0.82 \pm 0.08^{\mathrm{A}}$ & $5.51 \pm 0.25^{\mathrm{B}}$ \\
\hline & $\mathrm{L}$ & $61.89 \pm 0.10^{\mathrm{A}}$ & $63.67 \pm 0.10^{\mathrm{A}}$ & $59.79 \pm 0.10^{\mathrm{B}}$ \\
\hline & a & $-16.28 \pm 0.27^{\mathrm{A}}$ & $-14.07 \pm 0.55^{\mathrm{B}}$ & $-15.03 \pm 1.55^{\mathrm{AB}}$ \\
\hline & $\mathrm{b}$ & $30.05 \pm 0.54^{\mathrm{A}}$ & $28.30 \pm 0.91^{\mathrm{B}}$ & $30.12 \pm 0.44^{\mathrm{A}}$ \\
\hline \multirow{5}{*}{2} & $\mathrm{pH}$ & $6.33 \pm 0.10^{\mathrm{A}}$ & $6.13 \pm 0.30^{\mathrm{B}}$ & $6.08 \pm 0.44^{\mathrm{B}}$ \\
\hline & WL & $2.72 \pm 0.01^{\mathrm{A}}$ & $3.41 \pm 0.36^{\mathrm{A}}$ & $11.45 \pm 0.78^{\mathrm{B}}$ \\
\hline & $\mathrm{L}$ & $60.05 \pm 0.10^{\mathrm{A}}$ & $60.05 \pm 0.10^{\mathrm{A}}$ & $54.61 \pm 0.10^{\mathrm{B}}$ \\
\hline & a & $-16.20 \pm 0.13^{\mathrm{A}}$ & $-12.97 \pm 0.70^{\mathrm{B}}$ & $-14.69 \pm 0.38^{C}$ \\
\hline & b & $29.63 \pm 0.33^{\mathrm{A}}$ & $27.49 \pm 0.50^{\mathrm{B}}$ & $28.93 \pm 0.13^{\mathrm{A}}$ \\
\hline \multirow{5}{*}{3} & $\mathrm{pH}$ & $6.32 \pm 0.08^{\mathrm{A}}$ & $6.10 \pm 0.09^{\mathrm{B}}$ & $5.84 \pm 0.09^{\mathrm{C}}$ \\
\hline & WL & $4.47 \pm 0.12^{\mathrm{A}}$ & $5.84 \pm 0.56^{\mathrm{B}}$ & $15.07 \pm 0.57^{\mathrm{C}}$ \\
\hline & $\mathrm{L}$ & $59.72 \pm 0.41^{\mathrm{A}}$ & $57.90 \pm 1.48^{\mathrm{A}}$ & $49.89 \pm 1.02^{\mathrm{B}}$ \\
\hline & a & $-13.15 \pm 1.01^{\mathrm{A}}$ & $-12.55 \pm 1.19^{\mathrm{A}}$ & $-13.43 \pm 1.05^{\mathrm{A}}$ \\
\hline & $\mathrm{b}$ & $28.82 \pm 0.42^{\mathrm{A}}$ & $25.43 \pm 0.56^{\mathrm{B}}$ & $27.26 \pm 0.69^{C}$ \\
\hline \multirow{5}{*}{5} & $\mathrm{pH}$ & $6.24 \pm 0.08^{\mathrm{A}}$ & $6.02 \pm 0.08^{\mathrm{B}}$ & $5.30 \pm 0.08^{\mathrm{C}}$ \\
\hline & WL & $8.82 \pm 0.18^{\mathrm{A}}$ & $11.88 \pm 0.11^{\mathrm{B}}$ & $16.87 \pm 1.70^{\mathrm{C}}$ \\
\hline & $\mathrm{L}$ & $56.38 \pm 1.80^{\mathrm{A}}$ & $55.86 \pm 1.46^{\mathrm{A}}$ & $44.59 \pm 0.06^{\mathrm{B}}$ \\
\hline & $\mathrm{a}$ & $-11.49 \pm 1.41^{\mathrm{A}}$ & $-10.52 \pm 0.77^{\mathrm{A}}$ & $-11.83 \pm 0.62^{\mathrm{A}}$ \\
\hline & $\mathrm{b}$ & $26.50 \pm 0.40^{\mathrm{A}}$ & $24.20 \pm 0.26^{\mathrm{B}}$ & $25.21 \pm 0.25^{\mathrm{C}}$ \\
\hline \multirow{5}{*}{7} & $\mathrm{pH}$ & $6.20 \pm 0.08^{\mathrm{A}}$ & $6.00 \pm 0.08^{\mathrm{B}}$ & $5.05 \pm 0.08^{\mathrm{C}}$ \\
\hline & WL & $10.43 \pm 0.67^{\mathrm{A}}$ & $12.64 \pm 0.51^{\mathrm{B}}$ & $16.30 \pm 1.08^{C}$ \\
\hline & $\mathrm{L}$ & $51.15 \pm 0.17^{\mathrm{A}}$ & $53.39 \pm 1.45^{\mathrm{B}}$ & $38.96 \pm 1.07^{\mathrm{C}}$ \\
\hline & $\mathrm{a}$ & $-10.16 \pm 0.89^{\mathrm{A}}$ & $-10.10 \pm 0.27^{\mathrm{A}}$ & $-11.79 \pm 0.83^{\mathrm{B}}$ \\
\hline & $\mathrm{b}$ & $25.27 \pm 0.25^{\mathrm{A}}$ & $22.50 \pm 0.52^{\mathrm{B}}$ & $23.72 \pm 0.62^{\mathrm{C}}$ \\
\hline
\end{tabular}

pH, WL, L, a, b: pH, weight loss, colour parameter; LPS, Chlorine: lettuce samples treated by the LPS and chlorine respectively; NTC: non-treated control; Values are means of three replicates and counts are expressed in $\log _{10} \mathrm{CFU} \mathrm{g}^{-1}$ ( \pm standard deviation); Means followed by different letters are significantly different $(\mathrm{p}<0.05)$ for each bacterial population.

affected most of the microbial quality. Based on this quality tested $4 \mathrm{~h}$ and $5 \mathrm{IU}$ can be considered the best time and the best dose for the application for keeping fresh-cut lettuce microbial quality. The effectiveness of LPS as a decontamination treatment was comparable with that of chlorine. Application of LPS according to the proposed protocol were effective in inhibiting the growth and survival of spoilage microorganisms associated to minimally processed vegetables, without affecting its Quality markers.

However, in order to increase and improve the efficiency of LPS, coupling with other substances with antimicrobial potential can be considered.

\section{References}

[1] Kim, D.-C., Lee, S.-E., Nahmgoong, B., Choi, M.-J., Jeong, M.-C. and Kim, B.-S. 
(1995) Freshness Prolongation of Crisphead Lettuce by Vacuum Cooling. Applied Biological Chemistry, 38, 239-247.

[2] Sapers, G.M. (2001) Efficacy of Washing and Sanitizing Methods for Disinfection of Fresh Fruit and Vegetable Products. Food Technology and Biotechnology, 39, 305311.

[3] Rico, D., Martin-Diana, A.B., Barat, J.M. and Barry-Ryan, C. (2007) Extending and Measuring the Quality of Fresh-Cut Fruit and Vegetables: A Review. Trends in Food Science and Technology, 18, 373-386.

[4] FAO/OMS (2006) Benefits and Potential Risks of the LPS of Raw Milk Preservation. Inform of the Technical Meeting FAO/OMS, 56. http://www.fao.org/ag/dairy.html

[5] Naidu, A.S. (2000) Lactoperoxidase, In: Naidu, A.S., Ed., Natural Food Antimicrobial Systems, CRC Press, Boca Raton, FL, 103-132. https://doi.org/10.1201/9781420039368.ch3

[6] Jacob, B.M., Antony, E.K., Sreekumar, B. and Haridas, M. (2000) Thiocyanate Mediated Antifungal and Antibacterial Property of Goat Milk Lactoperoxidase. Life Sciences, 66, 2433-2439.

[7] Marshall, V.M. and Reiter, B. (1980) Comparison of the Antibacterial Activity of the Hypothiocyanite Anion towards Streptococcus lactis and Escherichia coli. Journal of General Microbiology, 120, 513-516. https://doi.org/10.1099/00221287-120-2-513

[8] AFSSA (2003) Avis (Opinion) of AFSSA, The French Food Safety Agency on the Authorization of Using a Lactoperoxidase System as a Processing Aid for the Treatment of Fresh-Cut, Ready-to-Eat Salads. AFSSA-Saisine $n^{\circ}$ 2003-SA-0015; Linked Saisines $n^{\circ} 2002-S A-0167$ and n²001-SA-0169.

[9] Guireaud, J.P. (1998) Food Microbiology. Dunod, Paris.

[10] Martín-Diana, A.B., Rico, D. and Barry-Ryan, C. (2008) Green Tea Extract as a Natural Antioxidant to Extend the Shelf-Life of Fresh-Cut Lettuce. Innovative Food Science and Emerging Technologies, 9, 593-603.

[11] Reiter, B., Marshall, V.M., Björck, L. and Rosèn, C.G. (1978) Non-Specific Bactericidal Activity of the Lactoperoxidase-Thiocyanate-Hydrogen Peroxide System of Milk against Escherichia coli and Some Gram-Negative Pathogens. Infection and Immunity, 13, 800-807.

[12] Visalsok, T., Shigeru, H., Satoshi, Y. and Souichi, K. (2004) Effects of a Lactoperoxidase-Thiocyanate-Hydrogen Peroxide System on Salmonella enteritidis in Animal or Vegetable Foods. Food Microbiology, 93, 175-183.

[13] Sagoua, W., Ducamp, M.N., Loiseau, G. and De Lapeyre de Bellaire, L. (2011) Effect of Lactoperoxidase System on the Control of Colletotrichum musae on Bananas. Food Technology and Biotechnology, 49, 244-248.

[14] Le Nguyen, D.D., Ducamp, M.N., Dornier, M., Montet, D. and Loiseau, G. (2005) Effect of Lactoperoxidase System against Three Major Causal Agents of Disease on Mangoes. Journal of Food Protection, 68, 1497-1500. https://doi.org/10.4315/0362-028X-68.7.1497

[15] Björck, L. (1978) Antibacterial Effect of the Lactoperoxidase System on Psychotrophic Bacteria in Milk. Milk Science International, 45, 109-118.

[16] Garry, P., Christieans, S. and Cartier, P. (2003) Processes of Bio-Preservation. 12th JSMTV.

[17] Bourgeois, C.M. and Leveau, J.Y. (1991) Technical Analysis and Control in the Food Industry. In: Plusquellec, A., Ed., Plants Products, Lavoisier-Technical and Documentation Apria, Paris, 379. 
[18] Martín-Diana, A.B., Rico, D., Barry-Ryan, C., Frías, J.M., Henehan, G.T.M. and Barat, J.M. (2007) Efficacy of Steamer Jet-Injection as Alternative to Chlorine in Fresh-Cut Lettuce. Postharvest Biology and Technology, 45, 97-107.

[19] Agüero, M.V., Ponce, A.G., Moreira, M.R. and Roura, S.I. (2011) Lettuce Quality Loss under Conditions That Favor the Wilting Phenomenon. Postharvest Biology and Technology, 59, 124-131.

[20] Castaner, M., Gil, M.I., Ruiz, M.V. and Artes, F. (1999) Browning Susceptibility of Minimally Processed Baby and Romaine Lettuces. European Food Research and Technology, 209, 52-56. https://doi.org/10.1007/s002170050456

[21] Bolin, H.R. and Huxoll, C.C. (1991) Effect of Preparation Procedures and Storage Parameters on Quality Retention of Salad-Cut Lettuce. Journal of Food Science, 56, 60-62. https://doi.org/10.1111/j.1365-2621.1991.tb07975.x

[22] Seifu, E., Elna, M.B. and Donkin, E.F. (2005) Significance of the Lactoperoxidase System in the Dairy Industry and Its Potential Applications: A Review. Trends in Food Science and Technology, 16, 137-154.

[23] Thomas, E.L. (1981) Lactoperoxidase-Catalyzed Oxidation of Thiocyanate: Equilibria between Oxidized Forms of Thiocyanate. Biochemistry, 20, 3273-3280. https://doi.org/10.1021/bi00514a045

[24] Beuchat, L.R. and Brackett, R.E. (1990) Survival and Growth of Listeria monocytogenes on Lettuce as Influenced by Shredding, Chlorine Treatment Modified Atmosphere Packaging and Temperature. Journal of Food Science, 55, 755-758. https://doi.org/10.1111/j.1365-2621.1990.tb05222.x

[25] Delaquis, P.J., Stewart, S., Toivonen, P.M.A. and Moyls, L.A. (1999) Effect of Warm Chlorinated Water on the Microbial Flora of Shredded Iceberg Lettuce. Food Research International, 32, 7-14.

Submit or recommend next manuscript to SCIRP and we will provide best service for you:

Accepting pre-submission inquiries through Email, Facebook, LinkedIn, Twitter, etc. A wide selection of journals (inclusive of 9 subjects, more than 200 journals)

Providing 24-hour high-quality service

User-friendly online submission system

Fair and swift peer-review system

Efficient typesetting and proofreading procedure

Display of the result of downloads and visits, as well as the number of cited articles

Maximum dissemination of your research work

Submit your manuscript at: http://papersubmission.scirp.org/

Or contact ti@scirp.org 